\title{
Sour Cherry (Cerasus vulgaris Miller) Kernel Oil as the Novel Functional Edible Oil: Sensory Evaluation and Antioxidant and Physicochemical Properties
}

\author{
Maryam Kazempour-Samak, ${ }^{1}$ Ladan Rashidi $\mathbb{D}^{0},{ }^{2}$ Mehrdad Ghavami, ${ }^{1}$ Anoosheh Sharifan, ${ }^{1}$ \\ and Fakhrisadat Hosseini ${ }^{3}$ \\ ${ }^{1}$ Department of Food Science and Technology, Faculty of Agriculture Science and Research Branch, Islamic Azad University, \\ Tehran, Iran \\ ${ }^{2}$ Food Technology and Agricultural Products Research Center, Standard Research Institute, PO Box 31745-139, Karaj, Iran \\ ${ }^{3}$ Department of Biology Science, Faculty of Biotechnology, Alzahra University, Tehran, Iran
}

Correspondence should be addressed to Ladan Rashidi; 1.rashidi@standard.ac.ir

Received 1 February 2021; Revised 25 April 2021; Accepted 21 May 2021; Published 31 May 2021

Academic Editor: Alejandro Hernández

Copyright (c) 2021 Maryam Kazempour-Samak et al. This is an open access article distributed under the Creative Commons Attribution License, which permits unrestricted use, distribution, and reproduction in any medium, provided the original work is properly cited.

\begin{abstract}
This study aims to extract oil from fresh sour cherry kernel (Cerasus vulgaris Miller) using the cold press method. The oil content and moisture were obtained as $31.89 \%$ and $4 \%$, respectively. The organoleptic assessment of the oil was acceptable and the free fatty acid value was obtained as 1.36 ( $\mathrm{mg} \mathrm{KOH} / \mathrm{g}$ oil). In addition, peroxide value and anisidine index of sour cherry kernel oil were obtained as $0.99 \mathrm{meqO}_{2} / \mathrm{kg}$ oil and 0.15 , respectively. The predominant fatty acids were linoleic acid (42.34\%), oleic acid (35.45\%), $\alpha$-eleostearic acid $(9.34 \%)$, and palmitic acid (6.54\%), respectively. The kernel oil contained nine major triacylglycerols consisting of OLL (20.44\%), OOL (16.99\%), LLL (8.20\%), LLEl (7.28\%), PLO (7.24\%), OElO (5.03\%), OOO (4.70\%), ElLO (4.54\%), PLL (4.35\%), and POO (3\%), respectively. The most abundant sterol compounds were $\beta$-sitosterol (83.55\%), $\Delta 5$-avenasterol (6.8\%), sitostanol (4.8\%), campesterol (3.5\%), and stigmasterol (0.53\%), respectively. Also, antioxidant activity, total phenol content (TPC), total anthocyanin content (TAC), total flavonoid content (TFC), total tannin content (TTC), and total tocopherol content were obtained as $73.22 \%, 33.44 \mathrm{mg} \mathrm{GA} / \mathrm{g}$ dry matter, $177.84 \mathrm{mg} / \mathrm{L}, 46.37 \mathrm{mg} / \mathrm{g}$ dry matter, and $1.21 \mathrm{mg}$ GA/g dry matter, $832.5 \mathrm{mg} /$ $\mathrm{kg}$ oil, respectively. The amount of amygdalin in the oil sample was not detectable.
\end{abstract}

\section{Introduction}

Sour cherry (Prunus Cerasus L.) is a popular fruit belonging to the family of Rosacea, subfamily Prunoideae. Sour cherry is widely used across North America, Europe, and Asia. The global production of sour cherry fruit has increased during the past few years and has reached 14.1 to 38.1 million tons in the years 2006 to 2016 [1]. Nowadays, sour cherry can be used as a kind of fresh fruit as well as juice, dried product, syrup, additive, and jam. This fruit is a rich source of phytochemicals and nutraceuticals, including anthocyanins with bioactive properties such as antioxidation and anti-inflammation, which could inhibit tumor development and prevent colon cancer [1].
A large part (approximately 85\%) of the annual production of sour cherries is processed, which includes juice or concentrate and frozen pitless sour cherry that produces a large amount of waste (kernels and pomace). Now, the main part of these wastes is used as animal feed or is discarded, and only a very small amount of these byproducts can be used $[1,2]$. Sour cherry pomace is a very valuable and rich source of bioactive compounds, including anthocyanins, polyphenols, flavonols, and red and purple pigments, which can be applicable in food and pharmaceutical products [2]. Encapsulated bioactive compounds of sour cherry pomace have also been applied in the cookies formulation. Results showed that applying encapsulated bioactive components of 
sour cherry pomace improves the functional properties of the cookies and their stability during storage [3]. Sour cherry kernels are the other main byproducts during canning or freezing (also known as pit or stone), which make up about $7-15 \%$ of the total fruit weight [1]. In addition, this byproduct of sour cherry processing is a good source of phenolic and antioxidant compounds, fat, protein, and dietary fiber. One of the main components of the sour cherry kernel is oil (17-36\%), which is a rich source of polyunsaturated and monounsaturated fatty acids. Amino acids, such as lysine (known as an essential amino acid) and glutamic acid (dominant amino acid), minerals such as calcium and potassium, and B vitamins group (B1, B3, B5, and B6) are other valuable compounds found in sour cherry kernel [1]. This kernel contains high content of oil, which can be taken into account as a rich source of bioactive and valuable compounds. Yilmaz et al. (2013) reported the use of carbon dioxide $\left(\mathrm{SC}-\mathrm{CO}_{2}\right)$ to extract oil from sour cherry kernels [1]. Also, the bioactive compounds existing in the extracted oil from sour cherry kernel oil by the various solvents were detected and quantified [4]. It was reported that different methods such as solvent extraction, microwave, ultrasound, and supercritical fluid assisted extraction, enzymatic methods, and cold pressing can be used to extract oil from oilseeds [5]. Kernel oil from Prunus species, including sweet cherry ( $P$. avium L.), sour cherry ( $P$. cerasus L.), apricot (Prunus armeniaca L.), nectarine ( $P$. persica var. nectarina (Aiton) Maxim.), peach ( $P$. persica (L.) Batsch var. persica), and plum ( $P$. domestica L.) contains high levels of unsaturated fatty acids and bioactive compounds [6].

Cold press extraction of oil is one of the methods of mechanical extraction, which requires less energy than other oil extraction methods and is environmental friendly. High quality oils with unique properties can be extracted by this method at low temperature without using the solvent [7]. However, few studies were conducted on physicochemical and antioxidant properties, and quantification and detection of bioactive compounds of extracted oil from sour cherry kernel oil using cold press method. For example, amygdaline is a cyanogenic glycoside which is found in the seeds or kernels of some fruits, including sour cherry kernel (3.89 mg/g kernel). The lethal dose of amygdalin is $0.5-3.5 \mathrm{mg} / \mathrm{g}$ body weight (bw) [8]. Amygdalin can be decreased by different procedures, including soaking, drying, crushing, and fermentation. The very low amount of amygdaline is reported in the sour cherry kernel oil using cold press method [8].

This study aims to extract oil from Iranian sour cherry kernel (Cerasus vulgaris Miller) using cold press method. Then, the physicochemical properties of the sour cherry kernel, including oil, moisture, protein, ash, and carbohydrate contents, were determined. In addition, the sensory evaluation and physicochemical and antioxidant properties of the extracted sour cherry kernel oil, including peroxide value, acidity value, anisidine index, oxidative stability, fatty acid, sterol and triacylglycerol compositions, antioxidant activity percentage (AA), total phenol content (TPC), total flavonoid content (TFC), total anthocyanin content (TAC), total tannin content (TTC), and tocopherol content were investigated comprehensively.

\section{Materials and Methods}

2.1. Materials. Methanol, hexane, potassium hydroxide, hydrochloric acid $(\mathrm{HCl})$, potassium chloride $(\mathrm{KCl})$, FolinCiocalteu reagent, DPPH (2,2-diphenyl-1-picrylhydrazyl), quercetin, gallic acid (GA), 5 - $\alpha$-Cholestane, and sodium carbonate $\left(\mathrm{Na}_{2} \mathrm{CO}_{3}\right)$ were obtained from Merck Chemical Company, Darmstadt, Germany. The reference standard of FAMEs mixture (C4-C24), amygdalin standard, triglycerides mixture standard, and the reference sterol compounds were purchased from Sigma-Aldrich Company, USA.

2.2. Sampling and Preparing Sour Cherry Kernel. Sour cherries were collected in May 2019 from the sour cherry trees cultivated in an orchard located in Lavasan (Lavasan is a prosperous town in Shemiranat County, Tehran Province, Iran). The fresh cherry fruits were pitted. The kernels were washed using water, dried in the ambient temperature, between $25^{\circ} \mathrm{C}$ and $30^{\circ} \mathrm{C}$, and stored in the refrigerator at $4^{\circ} \mathrm{C}$ in sealed bags. The dried kernels were ground and finally sized. The fraction of particle sizes was between 1 and $3 \mathrm{~mm}$. The powder of the kernels was kept in the dark plastic tube at $-20^{\circ} \mathrm{C}$ until analysis.

2.2.1. Physicochemical Characterization of Sour Cherry Kernel. The oil, moisture, protein, total carbohydrate, ash and crude fiber contents of sour cherry kernel were determined according to the test methods described in the ISO 659, ISO 665, ISO 20483, ISO 11292, ISO 2171, and ISO 5498 , respectively $[9,10,11,12,13,14]$.

2.3. Extraction of Oilfrom Sour Cherry Kernel Using Cold Press Method. The sour cherry kernel oil was mechanically extracted using the laboratory cold press machine (cold press hydraulic oil press machine, model 6YY-270, power $2.2(\mathrm{~kW})$, Anyang Best Complete Machinery Engineering Co., Ltd, China). The temperature of the oil extraction process was not more than $35^{\circ} \mathrm{C}-40^{\circ} \mathrm{C}$. The oil was centrifuged and then filtered to remove foreign materials. The temperature of extracted oil after filtration was around $32^{\circ} \mathrm{C}$. The oil was kept in a dark bottle at $-20^{\circ} \mathrm{C}$ until analysis.

2.3.1. Physicochemical Properties and Sensory Analysis of Sour Cherry Kernel Oil. Sensory analysis was performed by the six trained panelists (age between 25 and 32 years old) from Standard Research Institute of Iran in terms of taste, color, and odor according to the ASTM E1627-19 method [15]. Moisture content, peroxide and acidity values, and anisidine index of the sour cherry kernel oil were determined according to the described test methods in the ISO 8534, ISO 3960, ISO 660, and ISO 6885, respectively [16-19]. Saponification value, unsaponifiable matter, iodine value, and oxidative stability of sour cherry kernel oil were determined 
according to the methods explained in the ISO 3657 , ISO 18609, ISO 3961, and ISO 6886, respectively [20, 21, 22, 23].

2.3.2. Fatty Acid, Triacylglycerols (TAGs), and Sterol Analyses of the Oil. Fatty acid methyl esters $\left(\mathrm{FAME}_{\mathrm{S}}\right.$ ) of sour cherry kernel oil were prepared according to the described method in the ISO 12966-4: 2015 and then were injected into the gas chromatography (GC) (Yung Lin 6100, Korea) equipped with a flame ionization detector (FID) [24]. Fatty acids composition of sour cherry kernel oil was measured by GC equipped with a CP-SIL88 capillary column $(100 \mathrm{~m} \times 0.25 \mathrm{~mm}$ i.d. with $0.2 \mu \mathrm{m}$ film thickness) (Varian Inc.). The temperatures of the injector and detector were adjusted to $260^{\circ} \mathrm{C}$ and $280{ }^{\circ} \mathrm{C}$, respectively. The program of temperature followed was $8 \mathrm{~min}$ at $165^{\circ} \mathrm{C}, 2^{\circ} \mathrm{C} / \mathrm{min}$ to $210^{\circ} \mathrm{C}$, and the split ratio was $1: 100$ [24].

TAGs composition of sour cherry kernel oil was gained by high-performance reverse phase chromatography (HPLC) (Young Lin 9100, South Korea) equipped with the refractive index detector (RI) and the LiChrosorb ${ }^{\circledR} \mathrm{RP}-18$ column of $250 \mathrm{~mm}$ length, $4 \mathrm{~mm}$ diameter, and $5 \mu \mathrm{m}$ particle size. The mobile phase was acetonitrile and acetone $(50: 50$, $\mathrm{v} / \mathrm{v}$ ) at the flow rate of $1 \mathrm{~mL} / \mathrm{min}$ and the column temperature of $45^{\circ} \mathrm{C}$ [25].

The individual and total sterol content of sour cherry kernel oil were determined based on the procedure explained in ISO 12228:2014 [26].

2.3.3. Amygdalin Content. The amygdalin content in sour cherry kernel oil was measured using the method developed by Pavlović et al. [8]. Briefly, $2 \mathrm{~g}$ of oil was weighted in the round-bottom flask $(100 \mathrm{~mL})$; then, $50 \mathrm{~mL}$ of ethanol was added and the mixture was boiled using a rotary evaporator for $120 \mathrm{~min}$ at $78.5^{\circ} \mathrm{C}$. The extract was filtered and ethanol completely evaporated in the vacuum oven at $30^{\circ} \mathrm{C}$. The final extract was put in a desiccator. Then, diethyl ether $(10 \mathrm{~mL})$ was added and mixed for $1 \mathrm{~min}$ at the ambient temperature to precipitate amygdalin. Diethyl ether was evaporated using the nitrogen gas. The dried residue was dissolved in the deionized water $(5 \mathrm{~mL})$, filtered using $0.2 \mu \mathrm{m}$ PTFE filter, and injected to the HPLC. The HPLC was equipped with the UV detector and the RP-18 column $(250 \mathrm{~mm} \times 4.6 \mathrm{~mm}$; $5 \mu \mathrm{m})$. The water: acetonitrile $(25: 75)$ as the mobile phase was applied. The flow rate was $1 \mathrm{~mL} / \mathrm{min}$ and the wavelength of detection was $210 \mathrm{~nm}$.

2.3.4. Extracting Phenolic Compounds. Polyphenol compounds were extracted using a mixture of ethanol: water (80 : 20) followed by sonication for $5 \mathrm{~min}$ [25].

(1) Determining of Bioactive Compounds

(1) Total Phenol Content (TPC). By colorimetric assay, TPC in the ethanolic extract of sour cherry kernel was measured [25]. In addition, $200 \mu \mathrm{L}$ of sour cherry kernel oil extract, $800 \mu \mathrm{L}$ of deionized water, and $100 \mu \mathrm{L}$ of Folin-Ciocalteu reagent were mixed. The mixture was incubated for $3 \mathrm{~min}$ at room temperature. Then, $300 \mu \mathrm{L}$ of sodium carbonate $\left(\mathrm{Na}_{2} \mathrm{CO}_{3}\right)(20 \%(\mathrm{w} / \mathrm{v}))$ was added to the mixture and incubated again for $2 \mathrm{~h}$ in a dark place at $25^{\circ} \mathrm{C}$. The absorbance of the solution was obtained using UV/ Vis Spectrometer (Lambda 25-Perkin Elmer, USA) at $765 \mathrm{~nm}$. In the range of $0-100 \mu \mathrm{g} / \mathrm{mL}$, the calibration curve of gallic acid (GA) standard was obtained. TPC was represented as mg GA equivalent per g dry matter $[1,25]$. All the tests were done in triplicate.

(2) Total Tannin Content (TTC). The quantity of TTC of sour cherry kernel oil extract was determined using UV/Vis spectrometer (Lambda 25-Perkin Elmer, USA) at $725 \mathrm{~nm}$. TTC was expressed as GAE/g dry matter. Firstly, $100 \mu \mathrm{L}$ kernel oil extract was added to $750 \mu \mathrm{L}$ distilled water. Then, $500 \mu \mathrm{L}$ Folin-Ciocalteu reagent and $1000 \mu \mathrm{L}$ of sodium $(35 \%(\mathrm{w} / \mathrm{v}))$ were mixed. At room temperature, the mixture was shaked and diluted to $10 \mathrm{~mL}$ with distilled water and incubated for $30 \mathrm{~min}$. As mentioned, the calibration curve of the GA standard solution was prepared in the range $0-100 \mu \mathrm{g}$. All the tests were conducted in triplicate [25].

(3) Total Flavonoid Content (TFC). TFC of the sour cherry kernel was determined with the colorimetric assay and expressed as $\mathrm{mg}$ quercetin equivalent (QE)/g dry matter [25]. Briefly, at room temperature, $150 \mu \mathrm{L}$ of sodium nitrite $\left(\mathrm{NaNO}_{2}\right)(5 \%(\mathrm{w} / \mathrm{v}))$ was added to $200 \mu \mathrm{L}$ of kernel oil extract and incubated for $6 \mathrm{~min}$. Then, $150 \mu \mathrm{L}$ of $\mathrm{AlCl}_{3} \cdot 6 \mathrm{H}_{2} \mathrm{O}(10 \% \mathrm{w} / \mathrm{v})$ was added and again incubated for $6 \mathrm{~min}$. Thus, $800 \mu \mathrm{L}$ of $\mathrm{NaOH}$ solution $(10 \%(\mathrm{w} / \mathrm{v}))$ was added to the mixture solution and incubated at room temperature for $15 \mathrm{~min}$. The control sample (blank), instead of kernel oil extract, was distilled water. The absorbance was recorded at $510 \mathrm{~nm}$. All the tests were performed in triplicate. The calibration curve of quercetin $(\mathrm{QE})$ standard was achieved in the range of $0-100 \mu \mathrm{g} / \mathrm{mL}$ (using $80 \%$ ethanol) [25].

(4) Antioxidant Activity Percentage (AA\%). The antioxidant activity percentage of the sour cherry kernel oil extract was determined according to the described method by Khadem et al. [25]. $1 \mathrm{~mL}$ of DPPH solution $(0.1 \mathrm{mM})$ was added to $3 \mathrm{~mL}$ of sour cherry kernel oil extract and, then, put it in a dark place for $30 \mathrm{~min}$ at room temperature. The absorbance of the sample was determined at $517 \mathrm{~nm}$ by UV/Vis spectrophotometer. Comparison of DPPH radical scavenging activity to the control was obtained using

DPPH scavenging activity $(\%)=\frac{A 0-A 1}{A 0} \times 100$,

where $A_{0}$ and $A_{1}$ are control absorbance and sample absorbance, respectively [25].

(5) Total Anthocyanin Content (TAC). TAC of the sour cherry kernel oil extract was measured based on different $\mathrm{pHs}$, including $\mathrm{pHs} 1$ (0.025 $\mathrm{M}$ potassium 
chloride) and 4.5 (0.4 M sodium acetate buffer) [25]. For this purpose, $0.1 \mathrm{~mL}$ of the extract was diluted to $10 \mathrm{~mL}$ using the buffer solution. The sample absorption was determined at both wavelengths 510 and $700 \mathrm{~nm}$. The TAC (expressed as mg cyaniding 3glucosude $/ \mathrm{mL}$ ) of the samples was obtained using

total anthocyanin content $(\mathrm{mg} / \mathrm{mL})$

$$
=\frac{(A \times \mathrm{MW} \times \mathrm{DF} \times 1000)}{(\varepsilon \times 1)},
$$

where MW is the molecular weight (cyanidin-3glucoside, $\mathrm{MW}=449.2$ ), $\mathrm{DF}$ is the dilution factor, and $\varepsilon$ is the molar absorptivity; pigment content was as $\varepsilon=26,900$.

Also, $\mathrm{A}$ is defined as differences in absorption and is calculated by

$$
A=\left(A_{510}-A_{700}\right) \mathrm{pH}_{1}-\left(A_{510}-A_{700}\right) \mathrm{pH}_{4.5} .
$$

(6) Tocopherols Content. Tocopherols content of sour cherry kernel oil extract was determined by the HPLC-UV (Yung Lin 9100, South Korea) equipped with the RP-18 column (250 mm length, $4 \mathrm{~mm}$ inner diameter, and $5 \mu \mathrm{m}$ particle size). The mobile phase was the mixture of acetonitrile and methanol (50: 50). For preparing the sample, $200 \mu \mathrm{L}$ of the sour cherry kernel oil was completely mixed with $800 \mu \mathrm{L}$ of 2-propanol and directly injected into the HPLC equipped with the UV detector, and the tocopherols were detected at $290 \mathrm{~nm}[27,28]$.

2.4. Statistical Analysis. All the data were statistically analyzed using SPSS (ver.11.0) software and displayed as mean \pm standard deviation (SD); the calculations were conducted in triplicate. The significance of the difference was explicated at $p$-values $\leq 0.001$. Analysis of variance was carried out by one-way ANOVA procedure. Consequential differences between the means were calculated by Duncan's multiple range tests.

\section{Results and Dissection}

The results of physicochemical properties of sour cherry kernel and its oil as well as antioxidant properties of extracted oil from Iranian sour cherry kernel were reported as follows.

\subsection{Physicochemical Composition of Sour Cherry Kernel.} The moisture percent of the sour cherry kernel was evaluated to stabilize these kernels against microbial and chemical spoilage during storage. The initial moisture content of sour cherry kernel is around $10 \%$ to $14 \%$. Results showed that dried sour cherry kernel had $4 \%$ moisture content and the extracted oil of it had $1.9 \%$ moisture. The moisture percentage of cherry kernels was low and this property preserved them safe for a long period without susceptibility to spoilage [4]. Results showed that the ash, crude protein, total carbohydrate, crude fiber, and oil contents of sour cherry kernel were obtained as $1.98 \%, 32.5 \%, 29.63 \%, 10.52 \%$, and $31.89 \%$, respectively. It was reported that a kind of cherry kernel had $3.2 \%$ of total ash, $29.3 \%$ of crude protein, $2.91 \%$ of sugars, $46.62 \%$ of carbohydrates, $30.3 \%$ of dietary fiber, $3.1 \%$ of moisture, and $17.0 \%$ of oil [1]. Another study reported that the sour cherry kernel was found to contain $22.5 \%$ of crude oil, $7.2 \%$ of moisture, and $4.4 \%$ of ash contents [29]. In a study, total carbohydrates, crude fiber, crude protein, ash, and oil contents were $34.5 \%, 9.5 \%, 25.3 \%, 4.6 \%$, and $26.0 \%$, respectively [30].

The oil content of sour cherry kernel was obtained as $31.89 \%$, which was higher than those reported for species Prunus cerasus [29]. It has also been stated that the oil content of sour cherry kernels' different cultivars, including Haritonovskaya, Latvijas Zemais, Shokoladnica, and Zentenes, was obtained as $37.1 \%, 36.2 \%, 36.06 \%$, and $35.2 \%$, respectively [4]. The oil yield in the kernels of various sour cherry species is attributed to the type of variety, climatic conditions, extraction methods, etc. [4].

\subsection{Physicochemical Properties of Sour Cherry Kernel Oil}

3.2.1. Peroxide Value (PV), Acidity Value (AV), Anisidine Index (AI), Oxidative Stability (OS), Sensory Evaluation, and Amygdaline Detection. It is generally found that the chemical properties of oils and fats directly affected their physical properties. The presence of specific functional groups in the structure of lipids not only affects their physical and chemical properties, but also influences the functional properties of fats as well as the purpose of their applications in food [29]. Table 1 shows the results of AV, PV, AI, and OS of sour cherry kernel oil. The peroxide value of this oil was obtained as $0.99 \mathrm{mEq} \mathrm{O}_{2} / \mathrm{kg}$ oil, which was lower than that of the specified limitation for cold pressed or virgin oils [31]. It was reported that the peroxide value of sour cherry kernel oil from Banat, Romania, was $1.2 \mathrm{mEq}$ $\mathrm{O}_{2} / \mathrm{kg}$ oil [29].

$\mathrm{AV}$ of this sour cherry kernel oil was obtained as $1.36 \mathrm{mg}$ $\mathrm{KOH} / \mathrm{g}$ oil, which was higher than that of the reported in another research for sour cherry kernel oil acid value, $1 \mathrm{mg}$ $\mathrm{KOH} / \mathrm{g}$ oil [29]. In another study, AV of sour cherry kernel oil was obtained as $1.45 \mathrm{mg} \mathrm{KOH} / \mathrm{g}$ oil [32]. The OS of sour cherry kernel oil was determined by the accelerated oxidation technique using the Rancimat instrument. The OS of Iranian sour cherry kernel oil was obtained $3.0 \mathrm{~h}$ at $110^{\circ} \mathrm{C}$, which was higher than the Turkish sour cherry kernel oil (1.3 h) [33]. The OS of Montmorency sour cherry (Prunus cerasus L.) pit oil was analyzed using differential scanning calorimetry (DSC) at $130^{\circ} \mathrm{C}$ and the OS was obtained as $30.30 \mathrm{~min}$ [32].

AI shows the secondary oxidation of oil and fat and determines the amount of aldehydes and ketones, which are the indicators of oxidation development and excessive oil deterioration. Based on the result, AI of sour cherry kernel oil was obtained 0.15 , which indicates the quality of oil is suitable. Iodine value exhibits stability against oxidation and a degree of unsaturation for applying oil in the industry. In addition, the saponification value was applied for evaluating 
TABLE 1: Quality parameters of sour cherry kernel oil.

\begin{tabular}{lccccccc}
\hline $\begin{array}{l}\text { Acid value }(\mathrm{mg} \\
\mathrm{KOH} / \mathrm{g} \text { oil })\end{array}$ & $\begin{array}{c}\mathrm{PV}\left(\mathrm{mEq} \mathrm{O}_{2} /\right. \\
\mathrm{kg} \text { oil })\end{array}$ & $\begin{array}{c}\text { Amygdalin } \\
\text { content }(\mathrm{mg} / \mathrm{g})\end{array}$ & $\begin{array}{c}\text { Anisidine } \\
\text { index }\end{array}$ & OS $(\mathrm{h})$ & $\begin{array}{c}\text { Iodine value }(\mathrm{mg} \\
\left.\mathrm{I}_{2} / \mathrm{g} \text { fat }\right)\end{array}$ & $\begin{array}{c}\text { Saponification value } \\
(\mathrm{mg} \mathrm{KOH} / \mathrm{g} \text { fat })\end{array}$ & $\begin{array}{c}\text { Unsaponifiable } \\
\text { matter }(\%)\end{array}$ \\
\hline $1.36 \pm 0.13$ & $0.99 \pm 0.08$ & $\mathrm{ND}$ & $0.15 \pm 0.02$ & $3.00 \pm 0.20$ & $130.99 \pm 0.22$ & $194.0 \pm 0.10$ & $0.89 \pm 0.01$ \\
\hline
\end{tabular}

Data are expressed as the means \pm SD for three replicates, $p \leq 0.001$.

the molecular weight of fatty acids and the chain length of the triacylglycerols in the edible fats and oils [32]. Results showed that iodine value and saponification value of the oil sample were obtained as $130.99 \pm 0.22$ ( $\mathrm{mg} \mathrm{I}_{2} / \mathrm{g}$ fat) and $194.0 \pm 0.10$ (mg KOH/g fat), respectively. In a study, the iodine value and saponification value for sour cherry kernel oil were reported as $122.5 \mathrm{mg} \mathrm{I}_{2} / 100 \mathrm{~g}$ fat and $183 \mathrm{mg} \mathrm{KOH} / \mathrm{g}$ fat, respectively [30]. The saponification value of sour cherry kernel oil was $193 \mathrm{mg} \mathrm{KOH} / \mathrm{g}$ fat [32].

The unsaponifiable matter in the edible oils contains the compounds, including volatile matters, sterols, triterpene and aliphatic alcohols, vitamins (tocopherols), pigments, $\beta$-carotene, and hydrocarbons (squalene). These compounds play a particularly critical function in the oxidative stability and shelf life of oils [34]. The amount of the unsaponifiable matter was obtained as $0.89 \pm 0.01 \%$, which was $0.72 \%$ for sour cherry kernel oil [32]. The presence of cyanogenic glycosides, such as amygdalin in apricot kernel and cherry kernel (as byproducts of food industry), which are suitable sources of protein and oil production, limits the consumption or application of these byproducts in the food or feed industries [8]. It was reported that hydrolysis of amygdalin produces benzaldehyde and cyanide. In this study, the calibration curve of amygdalin was obtained in the range of $0-100 \mu \mathrm{g} / \mathrm{mL}$. Limit of detection (LOD) was $1 \mu \mathrm{g} /$ $\mathrm{mL}$. The results showed that amygdalin was not detectable in the sour cherry kernel oil. The suitable linearity was between the peak areas and the prepared concentrations of amygdalin. The calibration curve equation was obtained: $Y=$ $(25.40 \times X)+20.35, X$ : concentration of amygdalin $(\mu \mathrm{g} / \mathrm{mL})$, $Y=$ the surface area of amygdalin peak in the sample and regression coefficient $(r)$ obtained 0.9956 . Savic Ivan et al. determined amygdalin in the plum kernel extract using HPLC-DAD, which was obtained as $3.97 \mathrm{mg} / 100 \mathrm{~g}$ dry residue [35]. The amounts of amygdalin in the apricot kernel and sour cherry kernel oil were $0.2 \mathrm{mg} / \mathrm{g}$ oil and $0.0046 \mathrm{mg} / \mathrm{g}$ protein isolates, respectively [8].

The sensory evaluation of the cold-pressed sour cherry kernel oil was carried out with six trained tasters [15]. All the tasters of the panel were trained in different characteristic attributes of cold-pressed sour cherry kernel oil flavors. They were familiar with the main defects of these oils such as aging and sediment, mold and moisture (smell), burnt and roasted (smell and taste), acidic (taste), sour (smell and taste), bitter (taste), oxidative decay or sharpness (smell), metal (taste), grain kernel similar to grain or fruit (smell), pure (smell and taste), and freshness (taste). The oil samples $(15 \mathrm{~mL})$ were served in the special vessels at room temperature. The flavor and taste of the oils were characterized according to the sensory description form. Indicators of negative sensory evaluations, including burn taste and smell, acidity, bitter taste, pungent smell, and metallic taste of the sample and positive sensory evaluation indicators of grain kernel (similar to grain or fruit) as purity and freshness were checked [15]. Results showed that the appearance of the sour cherry kernel oil sample was observed without impurities at $20^{\circ} \mathrm{C}$ for $24 \mathrm{~h}$. The oil of sour cherry kernel was clear. The smell of the cold-pressed oil of sour cherry kernel was similar to that of bitter almonds. The color of sour cherry kernel oil was yellow and its flavor was slightly sweet. No defects were observed in the sour cherry kernel oil.

\subsubsection{Fatty Acids Composition. The results of fatty acids} composition of sour cherry kernel oil are shown in Table 2. The UFA content (88.80\%) was higher than that of SFA level (11.2\%) and PUFA level (52.66\%) was more than that of MUFA level (36.14\%). The predominant fatty acids in sour cherry kernel oil were linoleic acid (42.34\%), oleic acid (35.45\%), $\alpha$-eleostearic acid (9.34\%), and palmitic acid (6.54\%), respectively, which constituted $93.67 \%$ of the total fatty acid composition. A higher ratio of $\Sigma$ UFAs to SFAs makes oil more susceptible to oxidation. According to the results, the ratio of $\Sigma \mathrm{UFA} / \Sigma \mathrm{SFA}$ was obtained 7.928 , which showed this oil was more susceptible to oxidation. However, nutritionists always recommend the consumption reduction of saturated fatty acids and the consumption increase of omega- 3 and omega- 6 fatty acids. Various factors such as climatic conditions, geographical area, species, harvest year, cultivar, and ripening stage are effective factors in fatty acid composition [36]. The fatty acids composition of this sour cherry kernel oil was similar to that reported in the other research. The composition of fatty acids extracted from the kernels of six sour cherry cultivars showed that the most abundant fatty acids detected were linoleic acid (35.50-46.06\%), oleic acid (25.25-45.30), $\alpha$-eleostearic acid (7.43-15.76\%), and palmitic acid (5.06-7.38\%) [4]. The amounts of SFAs in these varieties ranged from $9.40 \%$ to $11.7 \%$ and their MUFAs and UFAs ranged from 26 to $46.10 \%$ and 44 to $62.30 \%$, respectively [4]. Oleic acid and linoleic acid of sweet cherry seed oil were in the range of $42.625 \%$ to $55.265 \%$ and $23.276 \%$, respectively [37]. The presence of $\alpha$-eleostearic fatty acid in the oil extracted from the sour cherry kernel of Turkey has not been reported [1]. However, the presence of $\alpha$-eleostearic acid (7.43-15.76\%) in oils extracted from six sour cherry cultivars of the Baltic countries and Russia has been reported [4].

3.2.3. Triacylglycerols (TAGs) Composition. The amount of each triglyceride corresponding to TAGs was obtained by HPLC equipped with refractive index [25] (Table 3). It was found that the most abundant TAGs found in sour cherry kernel oil were oleodilinolein (OLL) $(20.44 \%)$, dioleolinolein (OOL) (16.99\%), trilinolein (LLL) (8.20\%), 
TABLE 2: Fatty acid composition of sour cherry kernel oil.

\begin{tabular}{lcc}
\hline Fatty acid & Short name & Value (\%) \\
\hline Caprylic acid & C $8: 0$ & $0.06 \pm 0.02$ \\
Capric acid & $\mathrm{C} 10: 0$ & $0.07 \pm 0.01$ \\
Lauric acid & $\mathrm{C} 12: 0$ & $0.11 \pm 0.03$ \\
Myristic acid & $\mathrm{C} 14: 0$ & $0.08 \pm 0.01$ \\
Myristoleic acid & $\mathrm{C} 14: 1 \mathrm{c}$ & $0.03 \pm 0.02$ \\
Palmitic acid & $\mathrm{C} 16: 0$ & $6.54 \pm 0.12$ \\
Palmitoleic acid & $\mathrm{C} 16: 1 \mathrm{c}$ & $0.50 \pm 0.23$ \\
Heptadecanoic acid & $\mathrm{C} 17: 0$ & $0.13 \pm 0.01$ \\
Cis-Heptadecenoic acid & $\mathrm{C} 17: 1 \mathrm{c}$ & $0.10 \pm 0.02$ \\
Stearic acid & $\mathrm{C} 18: 0$ & $2.03 \pm 0.04$ \\
Oleic acid & $\mathrm{C} 18: 1 \mathrm{c}$ & $35.45 \pm 0.24$ \\
Linolelaidic acid & $\mathrm{C} 18: 2 \mathrm{t}$ & $0.39 \pm 0.01$ \\
Linoleic acid & $\mathrm{C} 18: 2 \mathrm{c}$ & $42.34 \pm 0.26$ \\
Arachidic acid & $\mathrm{C} 20: 0$ & $0.87 \pm 0.01$ \\
Linolenic acid & $\mathrm{C} 18: 3 c^{\delta}$ & $0.13 \pm 0.02$ \\
$\gamma$-linolenic acid & $\mathrm{C} 18: 3 \mathrm{c}^{\gamma}$ & $0.46 \pm 0.03$ \\
$\alpha$-Eleostearic acid & $\mathrm{C} 18: 3 \mathrm{c}^{\alpha}$ & $9.34 \pm 0.36$ \\
Eicosenoic acid & $\mathrm{C} 20: 1 \mathrm{c}$ & $0.03 \pm 0.01$ \\
Behenic acid & $\mathrm{C} 22: 0$ & $0.18 \pm 0.01$ \\
Erucic acid & $\mathrm{C} 22: 1 \mathrm{c}$ & $0.03 \pm 0.01$ \\
Lignoceric acid & $\mathrm{C} 24: 0$ & $0.14 \pm 0.01$ \\
$\Sigma$ UFA & - & $88.80 \pm 1.21$ \\
$\Sigma$ SFA & - & $11.20 \pm 0.27$ \\
$\Sigma$ PUFA & - & $52.66 \pm 0.68$ \\
$\Sigma$ MUFA & - & $36.14 \pm 0.53$ \\
$\Sigma$ UFA/ $\Sigma$ SFA & - & 7.928 \\
\hline D & & $p \leq 0.001$.
\end{tabular}

Data are expressed as the means \pm SD for three replicates, $p \leq 0.001$.

TABLE 3: TAGs composition of sour cherry kernel oil

\begin{tabular}{lccc}
\hline TAGs & Value $(\%)$ & TAGs & Value $(\%)$ \\
\hline LLL & 8.200 & SLL & 1.219 \\
ElElEl & 0.089 & ElElL & 1.619 \\
ElElO & 1.345 & ElPEl & 0.423 \\
LLEl & 7.287 & ElPO & 0.804 \\
OElO & 5.033 & ElLP & 0.968 \\
ElLO & 4.542 & ElSO & 0.225 \\
PoLL & 0.320 & PLO & 7.242 \\
OLnL & 0.574 & PLP & 0.559 \\
PoOLn & 0.008 & PoPP & 0.008 \\
PLnL & 0.122 & PoOP & 0.094 \\
PPoLn & 0.002 & LnPP & 0.008 \\
PoPoL & 0.004 & SPoL & 0.032 \\
PoPoPo & 0.000 & SOLn & 0.028 \\
SLnLn & 0.000 & OOO & 4.707 \\
OLL & 20.444 & POO & 3.009 \\
PoOL & 0.532 & POP & 0.464 \\
OOLn & 0.238 & SLL & 1.219 \\
PLL & 4.357 & PPoO & 0.094 \\
POLn & 0.150 & PLS & 0.636 \\
PPoPo & 0.008 & PoPP & 0.008 \\
PoOO & 0.147 & ElLS & 0.271 \\
PoPoO & 0.003 & SOL & 1.991 \\
PPoL & 0.113 & SOO & 0.015 \\
OOL & 16.990 & POS & 0.278 \\
PoOO & 0.147 & SLS & 0.156 \\
\hline
\end{tabular}

L: linoleic acid; O: oleic acid; P: palmitic acid; Po: palmitoleic acid; El: $\alpha$-eleostearic acid; S: stearic acid; Ln: linolenic acid dilinoleoeleostearin (LLEl) (7.28\%), palmitolinoleolein (PLO) (7.24\%), dioleoeleosteolin (OOEl) (5.03\%), triolein (OOO) (4.70\%), eleosteolinoleoolein (ElLO) (4.54\%), palmitoyldilinolein (PLL) $(4.35 \%)$, and palmitoyldiolein (POO) (3\%). There is no data on the identification of TAGs in sour cherry kernel oil. On sour cherry pit (Prunus cerasus L.) native to the USA (Payson, Utah, USA), it was found that the predominant TAGs were obtained in sour cherry pit oil, including OOO (16.83\%), OLO (16.64\%), LLO (13.20\%), OLP (7.25\%), OOP (6.49\%), and LEIL (6.16\%) [32]. There was little difference between these TAGs composition from the results obtained for sour cherry kernel oil TAGs in this study. It was reported that differences observed in each amount of triacylglycerol are probably due to the variations of geographical conditions, extraction method, and harvest time [32].

3.2.4. Composition of Sterols. Table 4 shows the sterols composition of sour cherry kernel oil. $\beta$-sitosterol $(83.55 \%)$ had the highest quantity among other constituent sterols. Other quantitatively major sterol compounds were $\Delta 5$ avenasterol $(6.8 \%)$, sitostanol $(4.8 \%)$, campesterol $(3.5 \%)$, and stigmasterol $(0.53 \%)$, respectively. It was reported that the dominant sterol compounds in this oil were $\beta$-sitosterol $(36.10 \mathrm{mg} / \mathrm{kg})$, campesterol $(1.59 \mathrm{mg} / \mathrm{kg})$, and stigmasterol $(7.2 \mathrm{mg} / \mathrm{kg})$ [32]. Atik et al. reported the sterol compounds of cold press sweet cherry kernel oil (Prunus avium). They found that the most abundant sterols in the sweet cherry kernel oil were $\beta$-sitosterol (88.93\%), campesterol (3.12\%), $\Delta 7$-stigmasterol $(2.48 \%), \Delta 5$-avenasterol $(2.12 \%)$, and sitosterol (1.42\%), respectively [38]. These differences may depend on the species differences, geographical area, and extraction methods [32].

3.2.5. TPC, TTC, TAC, TFC, Tocopherol Content, and Antioxidant Activity Percentage (AA\%). The results of TPC, TFC, TTC, AA\%, TAC, and tocopherols contents of sour cherry kernel oil extract are shown in Table 5. The used calibration curves equations for calculation of TPC, TTC, and TFC were obtained $Y=0.0224 X, R_{2}=0.9992$, $Y=0.0224 X, R_{2}=0.9992$, and $Y=0.0089 X+0.0766$ and $R_{2}=0.9997$, respectively. The TPC and AA\% of sour cherry oil extract were obtained as $33.44 \mathrm{mg} \mathrm{GA} / \mathrm{g}$ dry matter and $73.22 \%$, respectively (Table 5). Phenols are bioactive compounds capable of scavenging free radicals and antioxidant activity. These compounds are abundantly found in the plants and, as secondary metabolites, play an important role against oxidative stress. The presence of these compounds in the plant extracts is associated with their antioxidant activity. Therefore, the antioxidant activity of sour cherry kernel extract is related to its phenolic compounds [25]. The results also showed that the TTC, TFC, and TAC of the sour cherry kernel extract were obtained as $1.21 \mathrm{mg} \mathrm{GA} / \mathrm{g}$ dry matter, $46.37 \mathrm{mg}$ quercetin/g dry matter, and $177.84 \mathrm{mg}$ cyanidin 3glucoside equivalents $/ \mathrm{mL}$, respectively.

Based on the results, $\alpha$-tocopherol (325 mg/kg oil), $\gamma$-tocopherol (470 mg/kg oil), and $\delta$-tocopherol $(37.5 \mathrm{mg} / \mathrm{kg}$ oil) were the tocopherol compounds found in the extract of 
TABLE 4: Sterol composition of sour cherry kernel oil.

\begin{tabular}{lc}
\hline Sterol & Value (\%) \\
\hline Cholesterol & $0.08 \pm 0.01$ \\
Brassicasterol & $0.02 \pm 0.02$ \\
24-methylen-cholesterol & $0.02 \pm 0.00$ \\
Campesterol & $3.50 \pm 0.11$ \\
Campestanol & $0.20 \pm 0.03$ \\
Stigmasterol & $0.53 \pm 0.00$ \\
Delta (7) Campesterol & $0.10 \pm 0.01$ \\
Clerosterol & $0.40 \pm 0.06$ \\
Beta-Sitosterol & $83.55 \pm 5.28$ \\
Sitostanol & $4.80 \pm 0.26$ \\
Delta (5) Avenasterol & $6.80 \pm 0.18$ \\
Delta (5), (24) stigmastadienol & $1.40 \pm 0.10$ \\
D7-Stigmasterol & $2.30 \pm 0.04$ \\
D7-Avenasterol & $2.07 \pm 0.03$ \\
\hline
\end{tabular}

Data are expressed as the means \pm SD for three replicates, $p<0.001$.

TABLE 5: TPA, TTA, TAC, TFC, AA\%, and tocopherol contents of sour cherry kernel oil.

\begin{tabular}{lc}
\hline Property & Content \\
\hline Total phenol content (TPC) & $33.44 \pm 2.35(\mathrm{mg} \mathrm{GA} / \mathrm{g}$ dry matter) \\
Total tannin content (TTC) & $1.21 \pm 0.46(\mathrm{mg} \mathrm{GA} / \mathrm{g}$ dry matter) \\
Total flavonoid content & $46.37 \pm 3.87(\mathrm{mg}$ quercetin/g dry \\
(TFC) & matter) \\
Antioxidant activity & $73.22 \pm 4.21(\%)$ \\
Total anthocyanin content & $177.84 \pm 8.58(\mathrm{mg} \mathrm{cyanidin} 3-$ \\
(TAC) & glucoside $/ \mathrm{mL})$ \\
$\alpha$-tocopherol & $325.00 \pm 3.29(\mathrm{mg} / \mathrm{kg}$ oil $)$ \\
$\delta$-tocopherol & $37.50 \pm 2.22(\mathrm{mg} / \mathrm{kg}$ oil $)$ \\
$\gamma$-tocopherol & $470.00 \pm 5.22(\mathrm{mg} / \mathrm{kg}$ oil $)$ \\
Total tocopherol & $832.5 \pm 10.83(\mathrm{mg} / \mathrm{kg}$ oil $)$ \\
\hline
\end{tabular}

Data are expressed as the means \pm SD for three replicates.

sour cherry kernel. Thus, $\alpha$-tocopherol and $\gamma$-tocopherol are the two dominant tocopherols in sour cherry kernel oil extract. It was reported TPC and TAC values of the sweet cherry kernel oil were $22.1 \mathrm{mg} \mathrm{GAE} / \mathrm{g}$ of extract and $1.05 \mathrm{mmol} \mathrm{TE} / \mathrm{g}$ of extract, while $\alpha$-tocopherols and $\gamma$-tocopherol were $96.72 \mathrm{mg} / \mathrm{kg}$ oil and $57.40 \mathrm{mg} / \mathrm{kg}$ oil, respectively [38]. The sour cherry kernel extract (Prunus cerasus) is a rich source of bioactive compounds, including phenolics, antioxidant flavonoids, procyanidins, and anthocyanidins, which might be recommended to prevent vascular disease. Other studies have also confirmed the presence of $\alpha$-tocopherol, $\beta$-tocopherol, tocotrienols, tocopherol-like compounds, and squalene in sour cherry kernels. The presence of tocopherols as bioactive oil-soluble compounds in various species of sour cherry kernel was reported; four tocopherols $(\alpha, \beta, \gamma$, and $\delta)$ were found in the kernels of these fruits, where $\gamma$-tocopherol was the most abundant with a value in the range of $89.1 \mathrm{mg} / 100 \mathrm{~g}$ oil to $133.3 \mathrm{mg} / 100 \mathrm{~g}$ oil [4]. It was also reported that $\alpha, \gamma$, and $\delta$-tocopherols of sour cherry pit oil were obtained as $61(\mathrm{mg} /$ $\mathrm{kg}$ oil), 400 (mg/kg oil), and $64.2(\mathrm{mg} / \mathrm{kg}$ oil), respectively [32]. It was found that the amounts of tocopherols, carotenoids, tocotrienols, and lipophilic antioxidants in the extracted oils from 15 apricot kernels (Prunus armeniaca L.) as well as oil yield were affected by the genotype [39].

\section{Conclusion}

Oil scientists are continually looking for new sources of edible oils to introduce new potentials with unique properties. Sour cherry kernel is one of the byproducts of its fruit processing that can be used as a source of edible oil with unique bioactive properties. The oil extracted from sour cherry kernel contains a worthy source of lipophilic bioactive compounds including fatty acids, tocopherols, sterols, anthocyanins, and carotenoids. The Iranian sour cherry kernel oil contains further levels of total tocopherol $(832.5 \mathrm{mg} / \mathrm{kg}$ oil) and $\gamma$-tocopherol $(470 \mathrm{mg} / \mathrm{kg})$. The amygdalin content of sour cherry kernel oil was not detectable. In addition, $\alpha$-eleostearic acid with antitumor activity [4] had a considerable amount (9.34\%) in this oil. In this study, most data are presented for the first time for Iranian sour cherry kernel oil. Results of tests showed safety and quality of this oil, but with low oxidative stability of it leading to not having direct consumption of this oil by consumers. Results showed that sour cherry kernel oil contains valuable bioactive compounds, which can be used in food and cosmetic and pharmaceutical formulation industries.

\section{Data Availability}

The data used to support the findings of this study are included within the article.

\section{Conflicts of Interest}

There are no conflicts of interest.

\section{Authors' Contributions}

The corresponding author is responsible for ensuring that the descriptions are accurate and agreed by all authors. Dr. L. Rashidi conceived the idea, corrected the manuscript, and supervised the work. M. Kazempour carried out the experiments and wrote the manuscript. Dr. Mehrdad Ghavamia, Dr. Anoosheh Sharifana, and Dr. Fakhrisadat Hosseinic supervised the work and edited the manuscript.

\section{Acknowledgments}

The authors thank the Iranian National Organization for providing the materials and equipment.

\section{References}

[1] C. Yılmaz and V. Gökmen, "Compositional characteristics of sour cherry kernel and its oil as influenced by different extraction and roasting conditions," Industrial Crops and Products, vol. 49, pp. 130-135, 2013.

[2] J. Bajerska, S. Mildner-Szkudlarz, P. Górnaś, and D. Seglina, "The effects of muffins enriched with sour cherry pomace on 
acceptability, glycemic response, satiety and energy intake: a randomized crossover trial," Journal of the Science of Food and Agriculture, vol. 96, no. 7, pp. 2486-2493, 2016.

[3] V. T. Šaponjac, G. Ćetković, J. Čanadanović-Brunet et al., "Sour cherry pomace extract encapsulated in whey and soy proteins: incorporation in cookies," Food Chemistry, vol. 207, pp. 27-33, 2016.

[4] P. Górnaś, M. Rudzińska, M. Raczyk, I. Mišina, A. Soliven, and D. Seglina, "Composition of bioactive compounds in kernel oils recovered from sour cherry (Prunus cerasus L.) byproducts: impact of the cultivar on potential applications," Industrial Crops and Products, vol. 82, pp. 44-50, 2016.

[5] J. Azmir, I. S. M. Zaidul, M. M. Rahman et al., "Techniques for extraction of bioactive compounds from plant materials: a review," Journal of Food Engineering, vol. 117, no. 4, pp. 426-436, 2013.

[6] M. Natića, D. D. Zagorac, I. Ćirić, M. Meland, B. Rabrenović, and M. F. Akšić, "Cold pressed oils: green technology, bioactive compounds, functionality, and applications; chapter 56," Cold Pressed Oils from Genus Prunus, vol. 56, pp. 637658, 2020.

[7] B. Çakaloğlu, V. H. Özyurt, and S. Ötleş, "Cold press in oil extraction: a review," Ukrainian Food Journal, vol. 7, pp. 640-654, 2018.

[8] N. Pavlović, S. Vidović, J. Vladić et al., "Recovery of tocopherols, amygdalin and fatty acids from apricot kernel oil: cold pressing vs. Supercritical carbon dioxide," European Journal of Lipid Science and Technology, vol. 120, pp. 1-10, 2018.

[9] ISO 659, Oil Seeds Determination of Hexane Extract (Or Light Petroleum Extract), Called Oil Content, International Organization for Standardization, Geneva, Switzerland, 2009.

[10] ISO 665, Oilseeds Determination of Moisture and Volatile Matter Content, International Organization for Standardization, Geneva, Switzerland, 2020.

[11] ISO 20483, Cereals and Pulses-Determination of the Nitrogen Content and Calculation of the Crude Protein Content Kjeldahl Method, International Organization for Standardization, Geneva, Switzerland, 2013.

[12] ISO 11292, Instant Coffee: Determination of Free and Total Carbohydrate Contents-Method Using High-Performance Anion-Exchange Chromatography, International Organization for Standardization, Geneva, Switzerland, 1995.

[13] ISO 2171, Cereals, Pulses and By-Products-Determination of Ash Yield by Incineration, International Organization for Standardization, Geneva, Switzerland, 2007.

[14] ISO 5498, "Agricultural Food Products: Determination of Crude Fibre Content-General Method, International Organization for Standardization, Geneva, Switzerland, 1981.

[15] ASTM E1627, Standard Practice for Sensory Evaluation of Edible Oils and Fats, International Organization for Standardization, Geneva, Switzerland, 2019.

[16] ISO 8534, Animal and Vegetable Fats and Oils: Determination of Water Content-Karl Fischer Method (Pyridine Free), International Organization for Standardization, Geneva, Switzerland, 2017.

[17] ISO 3960, Animal and Vegetable Fats and Oils: Determination of Peroxide Value-Iodometric (Visual) Endpoint Determination, ISO, Geneva, Switzerland, 2017.

[18] ISO 660, Animal and Vegetable Fats and Oils-Determination of Acid Value and Acidity, ISO, Geneva, Switzerland, 2009.

[19] ISO 6885, Animal and Vegetable Fats and Oils-Determination of Anisidine Value, ISO, Geneva, Switzerland, 2016.
[20] ISO 3657, "Animal and Vegetable Fats and Oils-Determination of Saponification Value, International Organization for Standardization, Geneva, Switzerland, 2020.

[21] ISO 18609, Animal and Vegetable Fats and Oils Determination of Unsaponifiable Matter Method Using Hexane Extraction, International Organization for Standardization, Geneva, Switzerland, 2000.

[22] ISO 3961, Animal and Vegetable Fats and Oils-Determination of Iodine Value, International Organization for Standardization, Geneva, Switzerland, 2009.

[23] ISO 6886, Animal and Vegetable Fats and Oils-Determination of Oxidative Stability (Accelerated Oxidation Test), International Organization for Standardization, Geneva, Switzerland, 2016.

[24] ISO 12966-4, Animal and Vegetable Fats and Oils-Gas Chromatography of Fatty Acid Ethyl Esters-Part 4: Determination by Capillary Gas Chromatography, International Organization for Standardization, Geneva, Switzerland, 2015.

[25] S. Khadem, L. Rashidi, and M. Homapour, "Antioxidant capacity, phenolic composition and physicochemical characteristics of whole olive stone oil extracted from different olive varieties grown in Iran," European Journal of Lipid Science and Technology, vol. 121, no. 4, p. 1800365, 2019.

[26] ISO 12228, Animal and Vegetable Fats and Oils: Determination of Individual and Total Sterols Contents-Gas Chromatographic Method, International Organization for Standardization, Geneva, Switzerland, 2014.

[27] P. Górnaś, A. Soliven, and D. Segliņa, "Seed oils recovered from industrial fruit by-products are a rich source of tocopherols and tocotrienols: rapid separation of $\alpha / \beta / \gamma / \delta$ homologues by RP-HPLC/FLD," European Lipid Science and Technology, vol. 117, pp. 773-777, 2015.

[28] P. Górnaś, "Unique variability of tocopherol composition in various seed oils recovered from byproducts of apple industry: rapid and simple determination of all four homologues $(\alpha, \beta, \gamma$ and $\delta$ ) by RP-HPLC/FLD," Food Chemistry, vol. 172, pp. 129-134, 2015.

[29] V. Popa, C. Misca, D. Bordean, D. N. Raba, D. Stef, and D. Dumbrava, "Characterization of sour cherries (Prunus cerasus) kernel oil cultivars from Banat," Journal Agroaliment Process Technology, vol. 17, no. 4, pp. 398-401, 2011.

[30] E. S. Lazos, "Composition and oil characteristics of apricot, peach and cherry kernel," Grasas Y Aceites, vol. 42, no. 2, pp. 127-131, 1991.

[31] Codex Alimentarius Commission, "Codex committee on food hygiene. Propos. Draft guidel. Hyg. Reuse process. Water food plants," 2019.

[32] N. M. Korlesky, L. J. Stolp, D. R. Kodali, R. Goldschmidt, and W. C. Byrdwell, "Extraction and characterization of montmorency sour cherry (Prunus cerasus L.) pit oil," Journal of the American Oil Chemists' Society, vol. 93, no. 7, pp. 9951005, 2016.

[33] S. Uluata and N. Ozdemir, "Evaluation of chemical characterization, antioxidant activity and oxidative stability of some waste seed oil," Turkish Journal of Agriculture - Food Science and Technology, vol. 5, no. 1, pp. 48-53, 2017.

[34] S. Sánchez-Fidalgo, A. Cárdeno, M. Sánchez-Hidalgo et al., "Dietary unsaponifiable fraction from extra virgin olive oil supplementation attenuates acute ulcerative colitis in mice," European Journal of Pharmaceutical Sciences, vol. 48, no. 3, pp. 572-581, 2013.

[35] M. Savic Ivan, D. Nikolic Vesna, B. Nikolic Ljubisa, Z. Stankovic Mihajlo, and J. Res, "Development and validation of HPLC method for the determination of amygdalin in 
the plant extract of plum kernel," Chemistry Environment, vol. 16, no. 4, pp. 80-86, 2012.

[36] E. Sipeniece, I. Mišina, A. Grygier et al., "Impact of the harvest year of three cultivars of Japanese quince (Chaenomeles japonica) on the oil content and its composition," Scientia Horticulturae, vol. 275, pp. 109683-2021.

[37] M. Doğantürk and H. S. Canbay, "Oil ratio and fatty acid composition of cherry seed oil," Turkish Journal of Health Science and Life, vol. 2, no. 1, pp. 21-24, 2019.

[38] I. Atik, R. Sevik, and S. Karasu, "Characterization of some physicochemical properties of cold press sweet cherry (Prunus avium) seed oil," European Journal of Science and Technology, vol. 17, pp. 959-965, 2019.

[39] P. Górnaś, E. Radziejewska-Kubzdela, I. Mišina, R. BiegańskaMarecik, A. Grygier, and M. Rudzińska, "Tocopherols, tocotrienols and carotenoids in kernel oils recovered from 15 apricot (Prunus armeniaca L.) genotypes," Journal of American Oil Chemists Society, vol. 94, pp. 693-699, 2017. 